\title{
SEASONAL DISTRIBUTION AND COMMUNITY STRUCTURE OF MACROALGAE ALONG PORT SAID COAST, MEDITERRANEAN SEA, EGYPT
}

Fedekar F. Madkour ${ }^{1}$ and Gihan A. El-Shoubaky ${ }^{2}$ 1- Marine Science Department, Faculty of Science, Suez Canal University, Ismailia, Egypt.

2- Biological and Geological Sciences Department, Faculty of Education, Suez Canal University, Port Said, Egypt.

E-mail of corresponding author: fedekarmadkour @yahoo.com

Key words: Macroalgae eөmmunity, seasonal variation, Epiphytism, Porı Said,, Aediterranean.

\section{ABSTRACT}

Seasonal variations in macroalgae community inhabiting Port Said

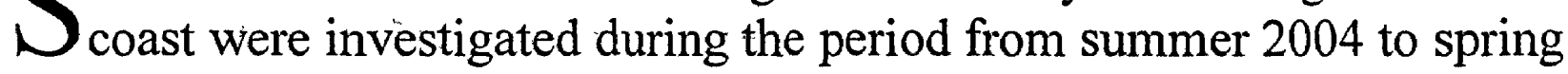
2005. Species composition and percent cover of macroalgae were studied in four sites distributed along the coast, representing different habitats. Some hydrographic parameters (temperature, salinity, $\mathrm{pH}$, dissolved oxygen, phosphate, nitrite, nitrate and silicate) were measured to determine the water characteristics influencing the studied sites. The study revealed the presence of 55 species, of them, 17 species have not been recorded previously in this area. The macroalgae comprised 31 species of Rhodophyta, 21 species of Chlorophyta and 3 species of Phaeophyta. Of the recorded species, 16 species occurred as epiphytes; most of them belonging to Rhodophyta. The most abundant species were Cladophpora prolifera, Enteromorpha compressa, E. prolifera, E. flexuosa, E. intestinalis, E. ralfsii, Ulva fasciata and U. rigida from Chlorophyta, and Gelidium crinale and Hypnea cornuta from Rhodophyta. There were relatively seasonal and spatial differences in the distribution patterns of species composition and abundance. Autumn and summer were the most diversified seasons. Site I which was away from any effluent, rich and diversified flora were observed relative to the other sites, with the highest abundance especially in Rhodophyta. The influence of the brackish water of Lake Manzala was obvious on the vegetation at site IV and sometimes at site III. 


\section{INTRODUCTION}

The eastern Mediterranean is distinguished by a great percentage of thermophile tropical and subtropical elements originating from three different sources: direct descendants of the Tethys Sea population which survived at various niches; immigrants from the Indian Ocean through the subsequent Pliocene communications or from the Red Sea (Băcescu, 1985). In general, most of the species comprise the present day marine flora of the Mediterranean originated in the Atlantic Ocean (Cinelli, 1985). The opening of the Suez Canal in 1869 allowed the introduction and settlement of hundreds of Indo-Pacific organisms to the Mediterranean, while only a few species have been succeeded to cross in the opposite direction (Aleem, 1948, 1950; Por, 1978, 1990; Halim, 1990; Fishelson, 2000; Galil et al., 2002; Golani et al., 2002; Zenetos et al., 2003). These immigrant species may have reached the Mediterranean from the Red Sea by either passive "one jump" or "step by step" migration (Lipkin, 1972).

Although Port Said coast is one of the Egyptian coasts in the Mediterranean Sea, which contains benthic macroalgae fouling its beaches, the benthic algal vegetation of Alexandria shoreline only has been relatively well documented (Aleem, 1993). Apart from few studies that were carried out on the algae inhabiting the jetty of Port Said and the connection of Lake Manzala with both of the Mediterranean and the Suez Canal (Aleem, 1980; Shaaban et al., 1983; El-Shoubaky, 1995), no recent intensive quantitative studies on the distribution and temporal fluctuations of benthic macroalgae abundance were done on Port Said shoreline.

The importance of Port Said coastline arises from its proximity to the Suez Canal and Lake Manzala. The former allowed free exchange of Mediterranean and Red Sea flora and the latter provided the sea with a considerable amount of brackish water. Furthermore, the presence of the ncw eastern branch in the northern part of the Suez Canal (El-Tafriaa) during the last decades added further pathway for the ships passing through this area. Considering the significance of macroalgal communities, both as an indicator of pollution and in public awareness, it is important to show the seasonal variations in these communities in a quantitative way. Therefore, this study aimed to give information on the seasonal composition and abundance of the benthic macroalgae inhabiting the littoral area at Port Said shoreline. and the factors that may potentially influence their growth. 


\section{STRUCTURE OF MACROALGAE ALONG PORT SAID COAST}

\section{MATERIALS AND METHODS}

The investigated area

Port Said coastline is largely sandy or mixed with shell debris. Many places along the shore were protected from the sea erosion by rock pavements and boulders. These rocks gave the shore a new configuration and represented a suitable substrate for benthic macroalgal growth. The investigated area covers the coastline between longitudes $32^{\circ} 20^{\prime} 30^{\prime \prime} \mathrm{E}$ and $32^{\circ} 10^{\circ} 56^{\prime \prime} \mathrm{E}$. Four sites were selected (Fig. 1) extending from the east corner near to El-Tafriaa (site I) which is away from any effluent. Site II is near the entrance of the Suez Canal (near to the port), which is affected by different human activities. Site III is located at El-Gameel, a short distance from the connection of Lake Manzala with the Mediterranean. Site IV lies at the entrance of Lake Manzala to the Mediterranean Sea and subjected to the brackish water discharges from Lake Manzala.

\section{Water analysis}

Samples of benthic macroalgae and seawater were collected during four successive seasons from summer 2004 to spring 2005. All parameters were measured in situ except nutrients: surface water temperature with a mercury thermometer; salinity with a refractometer (ATAGO, S/MILL, Model 8607); $\mathrm{pH}$ with a digital pH meter (Teleko AQUAMETER N 5211) and oxygen with oxygen meter (JENWAY, Model 9070). Water samples were collected using clean glass bottles to determine the nutrients (phosphate, nitrate, nitrite and silicate). The procedure used followed that described by Parsons et al. (1984).

Benthic macroalgae collection

The assessment of macroalgal abundance and distribution were performed using quadrate method of Russell and Fielding (1981). Macroalgal vegetation was described quantitatively through measuring percentage cover of each species inside the quadrate. The abundance of the species was assessed using the following seven numerical scales: $0.1<1,1=1-10,2=10-15,3=15-25,4=25-50,5=50-75$ and $6=75-100$. Benthic macroalgae were collected and preserved in $4 \%$ formalin. The collected macroalgae were examined and identified by Papenfuss (1968), Gribb (1983), Womersley $(1984,1987)$ and Aleem (1993). One way ANOVA and Pearson Product Moment (PPM) correlation coefficient were performed using SPSS V.12. 


\section{RESULTS}

\section{Water quality}

The physico-chemical parameters of the selected sites demonstrated characteristic variations between site IV and others (Table 1). Surface water temperature ranged between $15^{\circ} \mathrm{C}$ in winter and $29^{\circ} \mathrm{C}$ in summer. The salinity showed remarkable variation between sites giving the highest values at sites I and II all over the year (ranged between 38-39\%o). Site IV recorded the lowest values fluctuating between $14 \%$ and $32 \%$ in winter and summer respectively. The values of $\mathrm{pH}$ shifted towards the alkaline situation (8.10-8.37). The dissolved oxygen ranged between $5.18 \mathrm{mg} / \mathrm{l}$ at site IV in spring and $10.14 \mathrm{mg} / \mathrm{l}$ at site I in winter.

For all nutrient salts, site IV showed distinctive seasonal variations with exceptional high values that ranged between $0.63-3.36 \mu \mathrm{M}$ for phosphate, $0.42-1.46 \mu \mathrm{M}$ for nitrite, $2.65-8.32 \mu \mathrm{M}$ for nitrate, $11.93-22.73$ $\mu \mathrm{M}$ for silicate, giving the lowest values in summer and the highest values in winter. The low salinity and high nutrient levels at site IV are attributed to the brackish water discharges from Lake Manzala and extended to site III. On the other hand, the remaining sites recorded more or less similar concentrations with values that did not exceed $0.21 \mu \mathrm{M}$ for phosphate, $0.38 \mu \mathrm{M}$ for nitrite, $2.23 \mu \mathrm{M}$ for nitrate and for $4.20 \mu \mathrm{M}$ for silicate, without definite seasonal distribution pattern. ANOVA analysis showed significant differences $(p<0.05)$ between sites for all parameters except for temperature, but there were no significant seasonal differences. PPM correlation showed strong relationships $(-0.72<\mathrm{r}<-0.93)$ with high statistical significance $(p<0.01)$ between salinity and all nutrients, while positive correlation $(\mathrm{r}=0.51, p<0.05)$ was found between salinity and oxygen.

Floristic composition and description of algal community

Regardless of the blue green algae, a total of 55 species of benthic macroalgae were identified (Table 2). The taxonomic groups of the recorded species showed the dominance of Rhodophyta which were represented by 31 species comprising $56.4 \%$, with the dominance of genera: Hypnea (4 species), Gracilaria and Ceramium (3 species for each). Chlorophyta included 21 species (38.2\%), with the dominant genera of Enteromorpha ( 7 species), Ulva and Cladophora (3 species for each). Phaeophyta were negligible in terms of diversity ( 3 species) and abundance.

Of the recorded species, 16 species occurred as epiphytes; most of them belonging to Rhodophyta. Quantitatively, Achrochaetum unifilum, 
Ceramium spp., Fosliella farinose and Erythrotrichia carnea appeared as the predominant component of epiphytes (Table 2). On a seasonal scale, it was obvious that the epiphytic species flourished during summer and autumn. The most favorable macroalgae which usually overgrown by the epiphytic algae were Hypnea spp., Sarconema spp. Gracilaria spp. and Cladophora prolifera. Despite Fosliella farinose infested Cladophora prolifera and covered it with a high density, there was no preference between the epiphytes and the host. On the other hand, Achrochaetum unifilum showed wide distribution over most algae throughout the different seasons (ANOVA, $p<0.05$ ).

It is known that the habitat may determine the type of algal flora present and allow the dominance of particular species at the expense of others. In the present study, the upper littoral zone was occupied by darkly colored blue green algae community only in the low tide period. This community mixed with a few of Enteromorpha or Ulva when a considerable amount of water reached this level. The second community was characterized by Enteromorpha-Ulva community throughout all sites. Meanathite, Enteromorpha and Ulva alternate the vegetation when the substratum was sand mixed with shell debris. Cladophora-Gelidium community occupied a lower limit of vegetation at all sites. At site I, Hypnea community persisted as the lower limit of the littoral zone during the studied period and sometimes Sarconema community was mixed with it particularly in summer and autumn.

Seasonal variation of algal species composition and abundance

The study revealed that few species recorded throughout the whole year ( 6 species) or at least during three seasons ( 8 species) with equal contribution from Chlorophyta and Rhodophyta (Table 2). About half number of the recorded Species appeared in one season and belonged mainly to Rhodophyta, most of them flourished in autumn. As shown in Figure (2), there was a relative seasonal distribution pattern in the floristic composition with the highest number during autumn and summer. Chlorophyta exceeded Rhodophyta more or less during all seasons except in autumn, when the Rhodophyta was the dominant group. On the other hand, some relative differences in the floristic composition were observed between sites (Fig. 3). Site I showed the highest diversified species which was dominated by Rhodophyta. The other sites displayed approximately close number of species with dominance of Chlorophyta particularly from site IV. Phaeophyta was completely absent at site III. 
Considering the relative abundance of macroalgal divisions, Chlorophyta formed the highest coverage throughout the whole year, except at site I (Fig. 4). It displayed the highest percent value (100\%) at sites II and III in spring and at site IV in winter, while the lowest percent $(29.7 \%)$ was at site I in autumn. Conversely, Rhodophyta showed the most abundant species at site I during all seasons except in winter. The maximum abundance $(70.3 \%)$ occurred at site $\mathrm{I}$ in autumn and the minimum (2\%) was at site III in winter. The most abundant species were Cladophpora prolifera, Enteromorpha compressa, E. prolifera, E. flexuosa, E. intestinalis, E. ralfsii, Ulva fasciata and U. rigida from Chlorophyta, and Gelidium crinale and Hypnea cornuta from Rhodophyta.

\section{DISCUSSION}

The floristic list of the present work comprised 17 species of macroalgae more than those recorded by previous studies in Port Said (Aleem, 1980; Shaaban et al., 1983; Ei-Shoubaky, 1995). These species included 12 species of Rhodophyta (Acrochaetum unifilum, Antithamnion sp., Ceramium codii, C. gracillimum, C. tenuissimum, Champia irregularis, Coralina elongate, Hypnea valentiae, $H$. esperii, Polysiphonia variegata, Pterocladia nana and Sarconema filiformis), 4 species of Chlorophyta (Chaetomorpha linum, Enteromorpha clathrata, E. ralfsii and Rhizoclonium kochianum) and one of Phaeophyta (Pilayella litoralis). Although these species were recorded from different parts of the Mediterranean (Lipkin, 1972; Aleem, 1993; Gómez Garreta et al., 2001; El-Shoubaky, 2005), they have not been previously recorded in this area. Increasing the number of macroalgae inhabiting the investigated area is expected since the biota of the Eastern Mediterranean became more diversified (Por, 1978, 1990; Ahmed, 2005). This may be attributed to the Lessepsian immigration which could be accelerated as a result of decreasing the Bitter Lakes salinity, in addition to increase the salinity of the eastern Mediterranean, which became close to that of the Red Sea (after stopping of Nile flood). On the other hand, man-made modifications in the Port Said shoreline throughout the last decades gave a chance for establishment of more macroalgae species inhabiting this area. These modifications include the presence of rock pavements and boulders and the new eastern branch in the northern Suez Canal (ElTafreaa). 
Epiphytism is a wide spread phenomenon in marine benthic communities; a large numbers of marine algae can grow epiphytically on other macroalgae or seagrasses (Rindi and Guiry, 2004). In the present study, many algal species were recorded as epiphytes mostly from Rhodophyta such as Achrochaetum unifilum, Ceramium spp., Fosliella farinose and Erythrotrichia carnea. Most recorded epiphytes grew on one or more alga without preference, since most epiphytic algae are essentially facultative and not specifically associated with a host species (Wahl and Mark, 1999). In this case, epiphytes may utilize other algae as a substrate for physical support, regardless of the biological interaction between them and benefits from the host's buoyancy lifting it closer to the sunlight. On the other hand, some epiphytes are known as specific and obligate epibionts on certain hosts (Harlin, 1980; Pearson and Evans, 1990). This situation appeared in the association between Fosliella farinose and Cladophora prolifera which covered it:with a high density.

The present data showed that algal species subjected to seasonal and spatial variations with different degree either in species composition or abundance. These variations in algal vegetation are mainly related to the fluctuation in salinity and temperature. The algal vegetation was generally much more diverse in the period summer-autumn than in winter-spring. This highest diversity could be attributed to the species which appeared only in one season. These species increased with rising the temperature and showed optimum growth in autumn then subsequently began to diminish. This is especially notable at site I which was away from any effluents and characterized mainly by the high salinity and low nutrients. Hypnea cornuta, H. musciformis and Sarconema filiformis were the main contributors to the vegetation at this site.

The influence of the brackish water of Lake Manzala was obvious on the vegetation at site IV and sometimes at site III. These sites had the lowest values of salinity and the highest levels of nutrient loading particularly in winter. Most of the outflow waters from Lake Manzala to the sea was in winter, while the minimum was in summer (Aamer, 1999). These outflow waters bring diainage waters that were received by Lake Manzala from several drains, increasing the nutrient loading at this site. At these sites, Chlorophyta showed the highest abundance while Rhodophyta were quantitatively reduced in winter and spring. The vegetation was dominated by Enteromorpha, Ulva, Chaetomorpha and Cladophora from Chlorophyta together with Pterocladia nana and Gelidium crinale from Rhodophyta. These genera were reported to be 
flourished in the brackish water habitat (Aleem, 1980). Moreover, the brown alga Pilayella litoralis which characterizes the brackish water (Snoeijs, 1995) was observed in high abundance at site IV. At site II, flourishing growth of Ulva spp. especially $U$. fasciata was observed, such species characterizes areas exposed to human activities (Aleem, 1993).

\section{REFERENCES}

Aamer, M. A. (1999). Exchange of water and zooplankton organisms between Lake Manzala and Mediterranean Sea through Boughaz ElGamil. M. Sc. thesis, Suez Canal University, 344 pp.

Ahmed, A. I. (2005). The by-catch of shrimp beach seine in Lake Timsah, Suez Canal. Egyptian Journal of Aquatic Biology and Fisheries, 9 (4): 45-61.

Aleem, A. A. (1948). The recent migration of certain Indo-Pacific algae from the Red Sea into the Mediterranean. The new phyologist, 47: 88-94.

Aleem, A. A. (1950). Some new records of marine algae from the Mideterranean Sea, with reference to their geographical distribution. Meddl Gotenborg. Bot. Tradg., 18: 275-288.

Alcem, A. A. (1980). Contributions to the study of the marine algae of the Red Sea. IV-Algae and seagrasses inhabiting the Suez Canal. Bull. Fac. Sci. KAU. Jeddah, 4: 31-89.

Aleem, A. A. (1993). The marine algae of Alexandria. Egypt. Alexandria, $154 \mathrm{pp}$.

Băcescu, M. (1985). The effects of the geological and physico-chemical factors on the distribution of marine plants and animals in the Mediterranean. [In:] Mediterranean Marine Ecosystems. MoraitouApostolopoulou, M. and Kiortsis, V. (eds),pp. 195-212. 
Cinelli, F. (1985). On the biogeography of the benthic algae of the benthic algae of the Mediterranean. [In:] Mediterranean marine ecosystems. Moraitou-Apostolopoulou, M. and Kiortsis, V. (eds),pp. 49-56.

El-Shoubaky, G. A. (1995). Ecophysiological studies on some seaweeds of the Suez Canal. Ph D.Thesis., Suez Canal. Uni.

El-Shoubaky, G. A. (2005). Seasonal variations of seaweeds at El-Arish coast of Mediterranean Sea (Egypt). Egyptian J. Phycol., 6: 38-55.

Fishelson, L. (2000). Marine animal assemblages along the littoral of the Israeli Mediterranean seashore: the Red-Mediterranean Seas communities of species. Italian Journal of Zoology, 67: 393-415.

Galil, B.; Frogilia, C. and Noël, P. (2002). Crustaceans: decapods and stomatopods. CIESM Atlas of exotic species in the Mediterranean (ed. F. Briand), Monaco: CIESM Puplishers.

Golani, D.; Orsi-Relini, L.; Massuli, E. and Quignard, J. P. (2002). Fishes. CIESM Atlas of exotic species in the Mediterranean (ed. F. Briand), Monaco: CIESM Puplishers.

Gómez Carreta, A.; Gallardo, T.; Ribera, M. A.; Cormaci, M.; Furnari, G.; Giaccone, G. and Boudouresque, C. F. (2001). Checklist of Mediterranean seaweeds. III. Rhodophyceae Rabenh. 1. Ceramiales Oltm., Botanica Marina, 44 (5): 425-460.

Gribb, A. B. (1983). Marine algae of the southern Great Barrier Reef. Part I. Rhodophyta. Australia Coral Reef Society.

Halim, Y. (1990). On the potential migration of Indo-Pacific plankton through the Suez Canal. Bull. Inst. Oceanogr., 7: 11-27.

Harlin, M. M. (1980). Seagrass epiphytes. In: Phillips, R.C., McRoy, C.P. (Eds.), Handbook of Seagrass Biology: An Ecosystem Perspective. Jarland STPM Press, New York, pp. 117- 151. 
Lipkin, Y. (1972). Marine algae and seagrass flora of the Suez Canal. Israel J. Zoology, 21 (3-4): 405-446.

Papenfuss, G. F. (1968). A history, catalogue and bibliography of Red Sea benthic algae. Israel J. Bot., 17: 1-118.

Parsons, T. R.; Maita, Y. and Lalli, C. M. (1984). A Manual of Chemical and Biological Methods for Seawater Analysis. Pergamon Press, Oxford.

Pearson, G.A. and Evans, L.V. (1990). Settlement and survival of Polysiphonia lanosa (Ceramiales) spores on Ascophyllum nodosum and Fucus vesiculosus (Fucales). J. Phycol., 26: 597-603.

Por, F. D. (1978). Lessepsian Migration- The Influx of Red Sea Biota into the Mediterranean by Way of the Suez Canal. Ecological Studies. Springer-Verlag, Berlin.

Por. F. D. (1990). Lessepsian migration. An apprasial and new data. Bull. Inst. Oceanogr., 7: 1-10.

Rindi, F.; and Guiry M. D. (2004). Composition and spatio temporal variability of the epiphytic macroalgal assemblage of Fucus vesiculosus Linnaeus at Clare Island, Mayo, western Ireland. Journal of Experimental Marine Biology and Ecology, 311: 233252

Russell, G. and Fielding, A. H. (1981). Individuals, populations and communities. [in:] The biology of seaweeds, Lobban, C. S. and Wynne, M. J. (eds.), Blackwell Scientific Puplications, Oxford, pp. 393-420.

Shaaban, A. M.; El-Habibi, A. M. and El-Naggar, M. E. (1983). Algal vegetation of the Mediterranean coast of Egypt. Egypt. J. Bot., 24 (3): 179-199. 


\section{SEASONAL DISTRIBUTION AND COMMUNITY

Snoeijs, P. (1995). Effects of salinity on epiphytic diatom communities on Pilayella litoralis (Phaeophyceae) in the Baltic Sea. Ecoscience, 2: 382-394.

Wahl, M. and Mark, O. (1999). The predominantly facultative nature of epibiosis: experimental and observational evidence. Mar. Ecol. Prog. Ser. 187: 59-66.

Womersley, H. B. S. (1984). The marine benthic flora of southern Australia. Part I (Gout Printer:Adelaide).

Womersley, H. B. S. (1987). The marine benthic flora of southern Australia. Part II (Gout Printer: Adelaide).

Zenetos, A.; Gofas, S.; Russo, G. and Templado, J. (2003). Atlas of exotic species in the Mediterranean (ed. F. Briand). Monaco: CIESM Puplishers. 


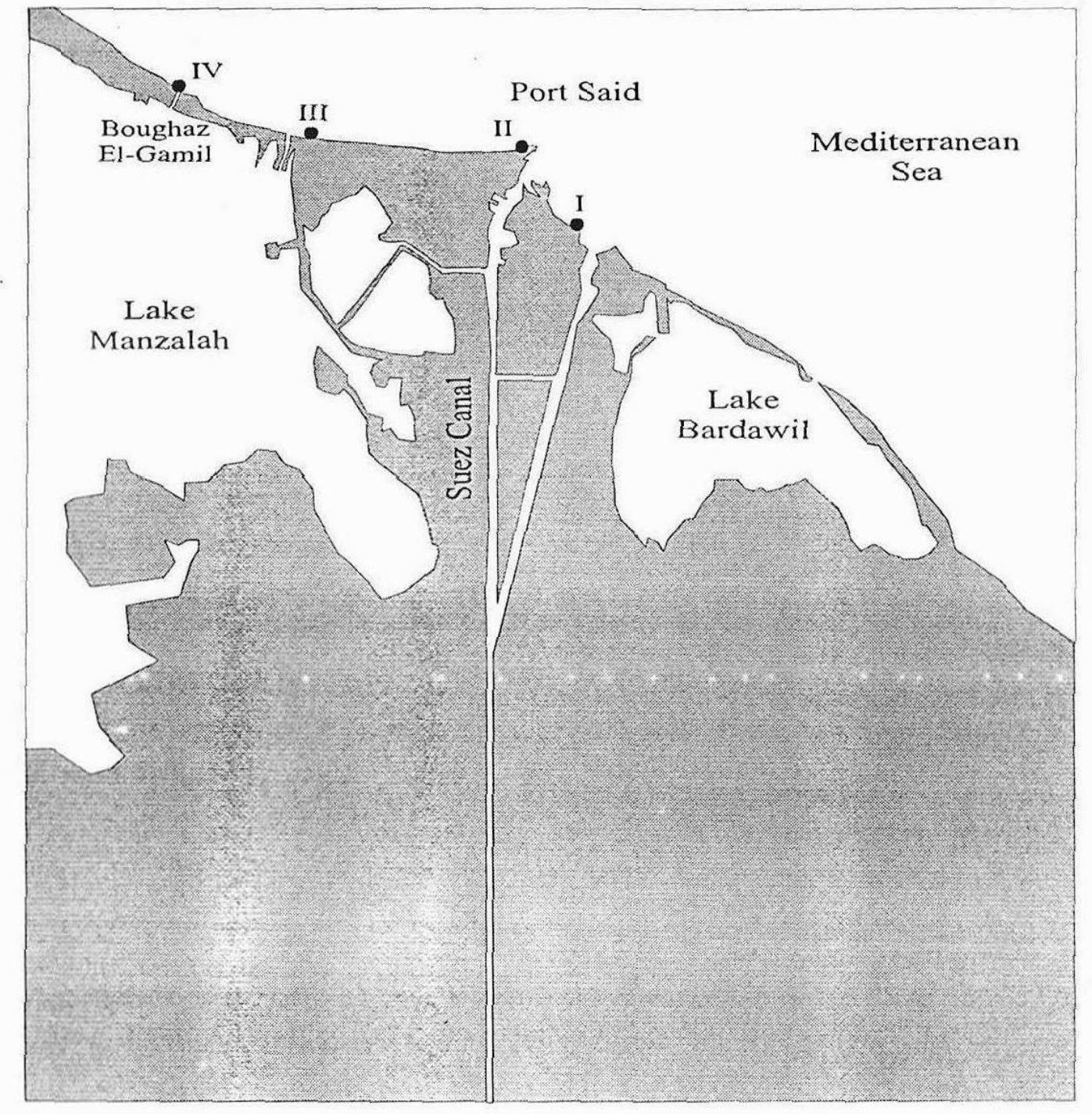

Figure (1). Map of investigated area showing the selected sites. 


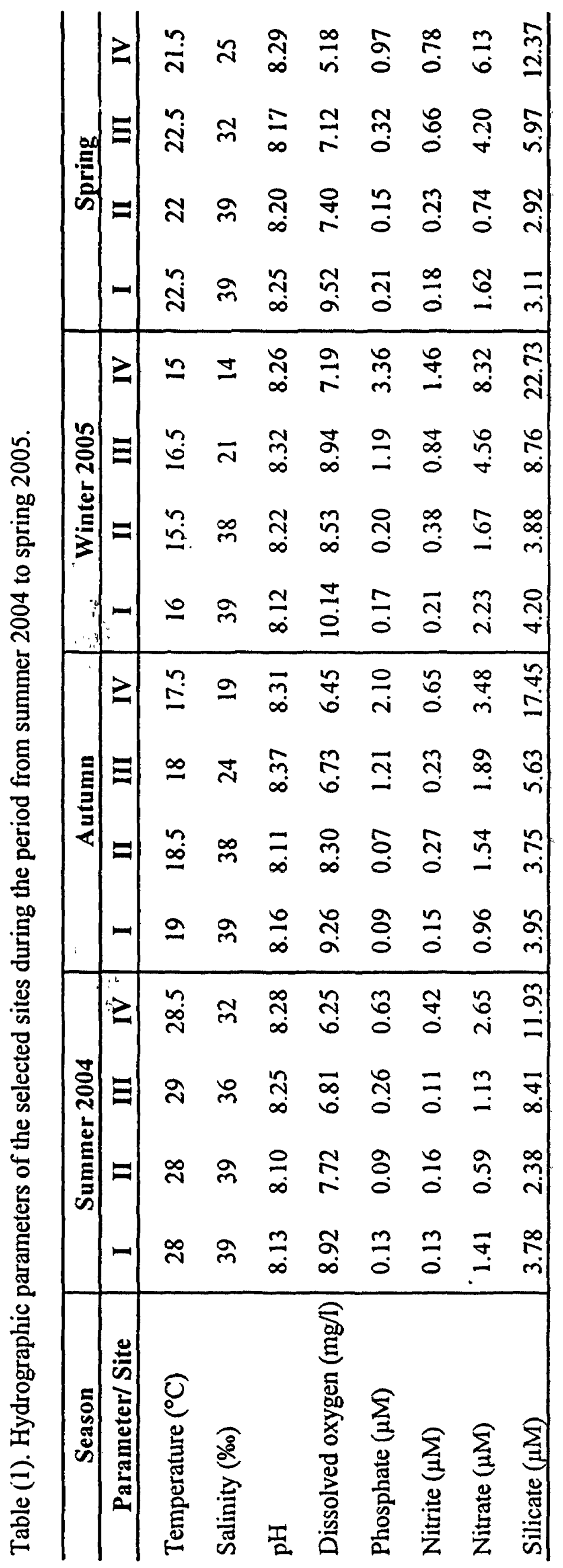


Table (2). Scasonal distribution of macroalgae along Port Said coast.

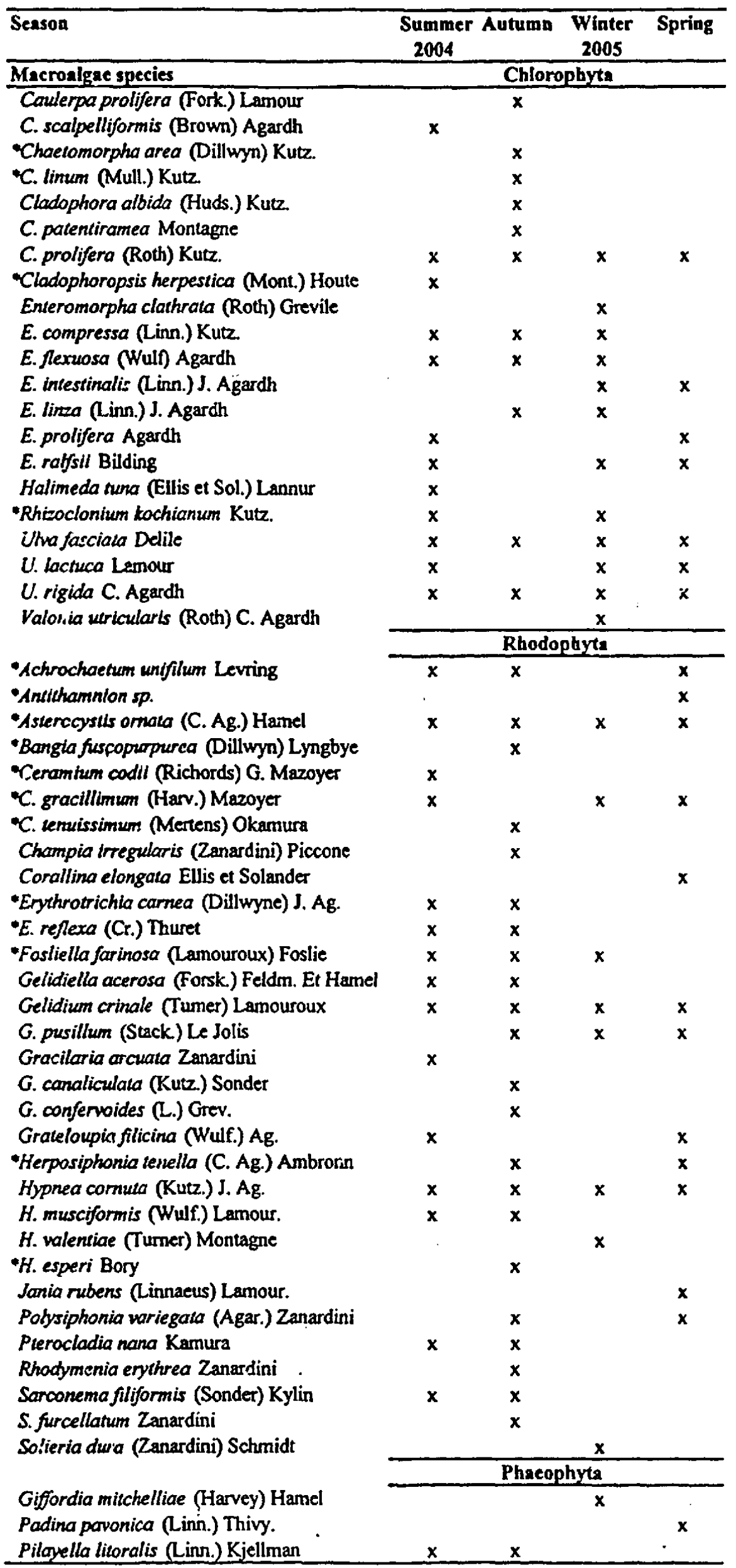

- epiphytic macroalgae 


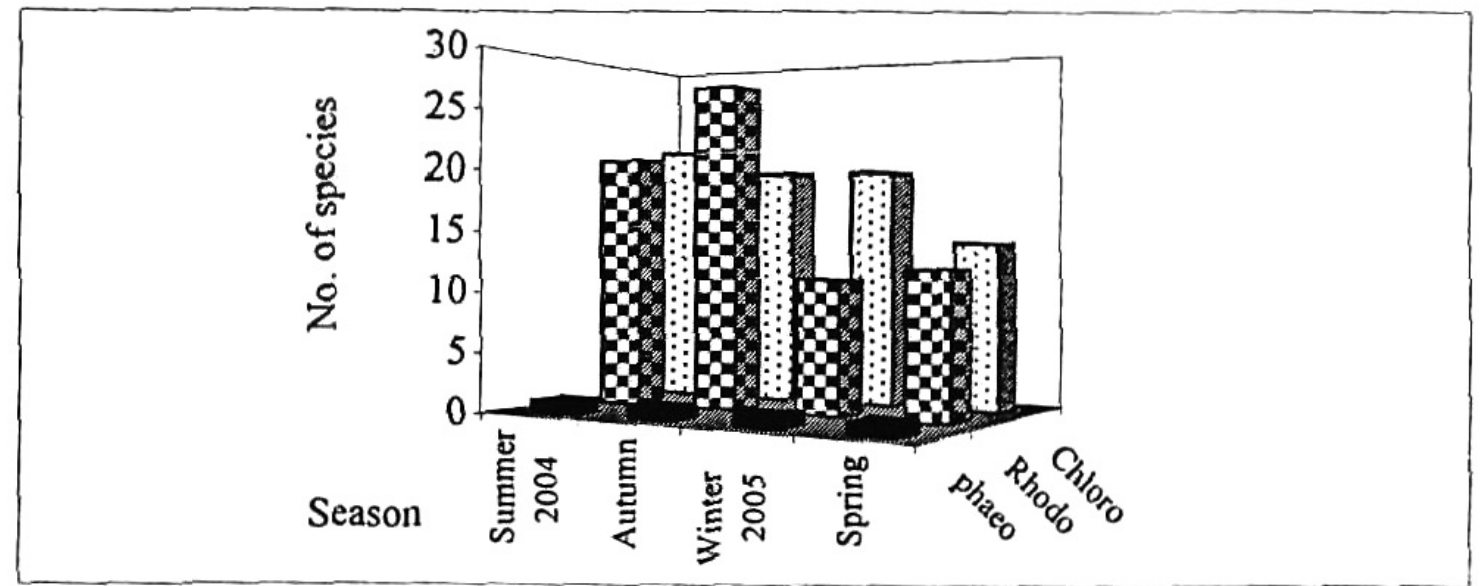

Figure (2). Seasonal variation of the species number in macroalgae divisions along Port Said coast.

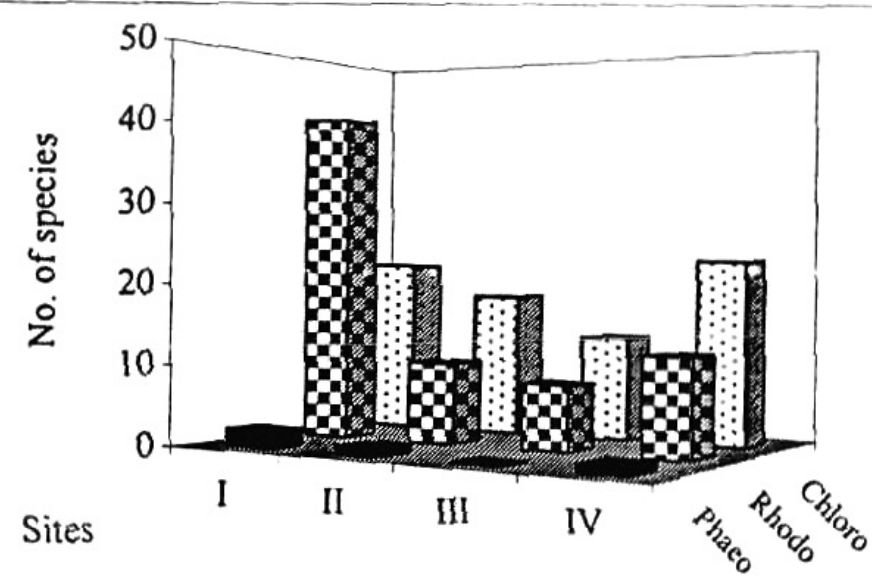

Figure (3). Spacial distribution of the species number in macroalgae divisions along Port Said coast.

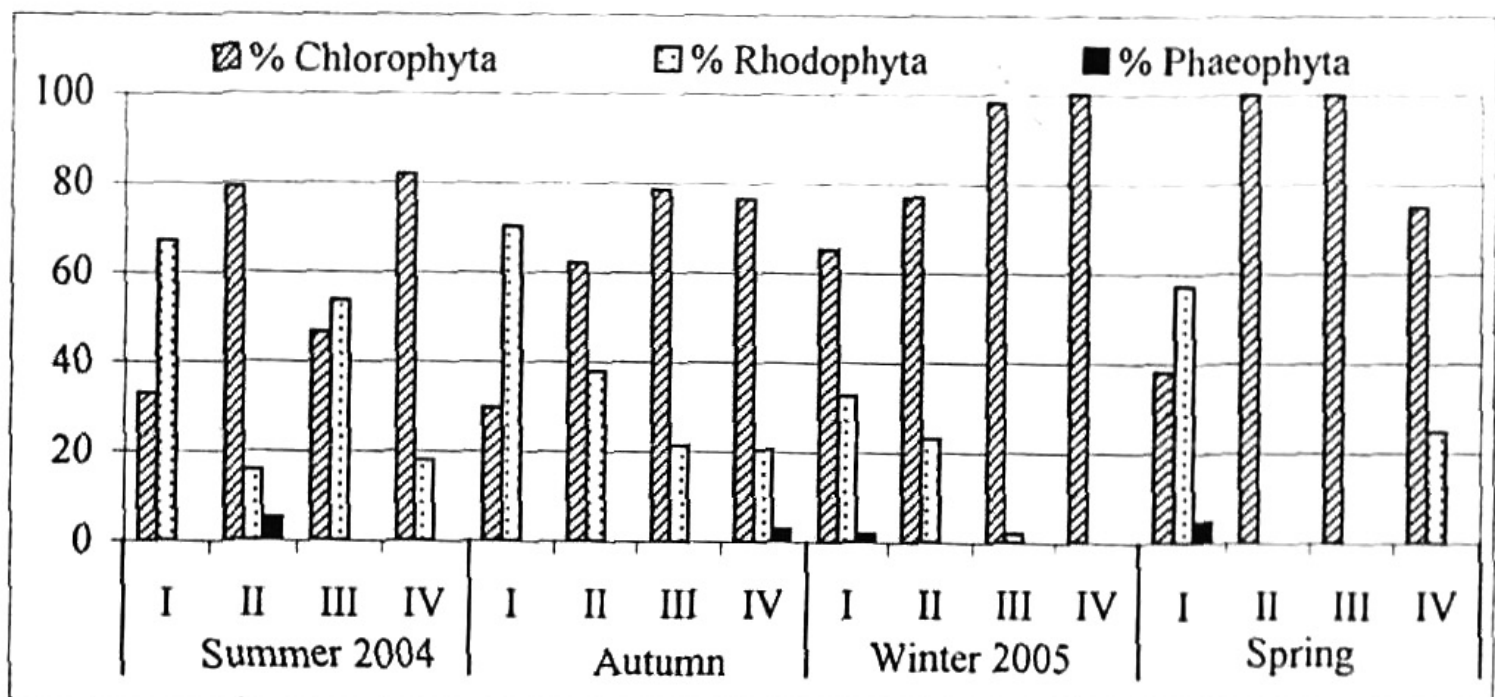

Figure (4). Seasonal relative abundance of macroalgal divisions along Port Said coast. 